\title{
COMPARISON OF EFFICACY OF ONDANSETRON, METOCLOPRAMIDE AND PLACEBO IN THE PREVENTION OF POST-OPERATIVE NAUSEA AND VOMITING IN PATIENTS UNDERGOING GYNAECOLOGICAL LAPAROSCOPY
}

\author{
Satheedevi Parameswaran1, Jayakumar Christhudas ${ }^{2}$
}

${ }^{1}$ Additional Professor, Department of Anaesthesiology, Government Medical College, Manjeri, Malappuram, Kerala. ${ }_{2}^{2}$ Associate Professor, Department of Anaesthesiology, Government Medical College, Manjeri, Malappuram, Kerala.

\section{ABSTRACT}

\section{BACKGROUND}

Post-operative Nausea and Vomiting (PONV) are one among the most common distressing symptoms occurring after surgery. Patients undergoing gynaecological laparoscopic surgery represents a susceptible group and anti-emetic prophylaxis will reduce these problems.

The objectives of this study is to compare the efficacy of Ondansetron, Metoclopramide and placebo in the prevention of postoperative nausea and vomiting in patients undergoing gynaecological laparoscopy.

\section{MATERIALS AND METHODS}

It is a clinical study of the comparison of efficacy of Ondansetron, Metoclopramide and placebo in the prevention of post-operative nausea and vomiting in 60 patients in the age group 20 - 39 years undergoing gynaecological laparoscopic surgeries. All of them belonged to ASA Grade I and II. The study was carried out at Government Medical College. The 60 patents were randomised to 3 groups of 20 each. To receive either Inj. Ondansetron 4 mg IV (Group I), Inj. Metoclopramide 10 mg IV (Group II) and Inj. 0.9\% normal saline as placebo (Group III). A double-blind design was used and the drugs were administered 5 minutes before induction of anaesthesia. All patients were assessed for fitness of anaesthesia pre-operatively and were given nil per oral 6 hours prior to surgery. The age and weight of the patients were noted. The basal heart rate, blood pressure and respiratory rate were noted for the comparison with the intra-operative and post-operative values. The time of induction and time of surgical incision was noted. Standard monitoring in all cases included pulse rate, BP, ECG and SPO2. The time of removal of laparoscope was noted. The time of recovery was noted. The duration of surgery and duration of anaesthesia were calculated and recorded. The data were analysed statistically by considering the variables such as age, weight, BP, heart rate respiratory rate, frequency of nausea, vomiting and other outcome measures and the effectiveness of two anti-emetic drugs were compared to the control group.

\section{RESULTS}

1). Both the study drugs had no significant effects on the vital signs of the patient; 2). Ondansetron had a higher anti-emetic effect compared to control group; 3). No significant differences were noted in the case of post-operative pain between the groups; 4). Ondansetron group took oral fluids earlier than other groups.

\section{CONCLUSION}

In conclusion, the study proved that Ondansetron was superior to Metoclopramide in gynaecological laparoscopy.

\section{KEYWORDS}

Ondansetron, Metoclopramide Serotonin, Dopamine.

HOW TO CITE THIS ARTICLE: Parameswaran S, Christhudas J. Comparison of efficacy of ondansetron, metoclopramide and placebo in the prevention of post-operative nausea and vomiting in patients undergoing gynaecological laparoscopy. J. Evolution Med. Dent. Sci. 2017;6(7):545-549, DOI: 10.14260/Jemds/2017/116

\section{BACKGROUND}

Post-operative Nausea and Vomiting (PONV) are among the most common distressing symptoms occurring after surgery. It remains a common problem after general anaesthesia and contribute to patient dissatisfaction with their ambulatory surgery experience. $(1,2)$ The chemoreceptor trigger zone and vomiting centre stimulates the upper GIT resulting in emesis.

Financial or Other, Competing Interest: None.

Submission 18-12-2016, Peer Review 11-01-2017,

Acceptance 17-01-2017, Published 23-01-2017.

Corresponding Author:

Dr. Satheedevi Parameswaran,

Additional Professor,

Department of Anaesthesiology,

Government Medical College,

Manjeri, Malappuram Kerala.

E-mail: drsathee171@gmail.com

DOI: $10.14260 /$ jemds $/ 2017 / 116$

(c) (i) $($ )
The cholinergic and dopaminergic pathways are integral part of it. Other factors also influence nausea and vomiting are age gender, menstrual cycle, motion sickness, anxiety, laparoscopy, anaesthesia, etc. $(3,4)$ Patients undergoing gynaecological laparoscopic surgery represents a susceptible group and anti-emetic prophylaxis will reduce these problems. A variety of risk scoring system has been developed in an attempt to improve the use antiemetic therapy.(5) Some of the commonly used anti-emetics in anaesthesia are -

1) Drugs with cholinergic activity - Scopolamine.

2) Butyrophenones-Droperidol.

3) Antihistamines-Dimenhydrinate and hydroxyzine.

4) Dopamine antagonists-Metoclopramide.

5) Serotonin antagonists-Ondansetron.

Ondansetron is a 5HT3 antagonist, which is administered orally or intravenously. Adult dose is $4-8 \mathrm{mg}$ with a plasma half-life of 3 hours and metabolised by hydroxylation in liver. 
It has a good safety profile and the side effects are constipation, headache, warm sensation and flushing. It is primarily used in the treatment of chemotherapy induced nausea and vomiting. It is also effective in preventing postoperative nausea and vomiting.

Metoclopramide is used for the treatment of PONV. It has both central and peripheral actions. Centrally, it blocks Dopamine at Chemoreceptor Trigger Zone (CTZ). Peripherally, it increases lower oesophageal sphincter tone and enhances gastrointestinal motility. It is short-acting and for PONV prophylaxis it should be given at the end of surgery. Its side effects are extrapyramidal symptoms and sedation.

The present study is to compare the efficacy of Ondansetron, Metoclopramide and placebo in the prevention of post-operative nausea and vomiting in patients undergoing gynaecological laparoscopy.

\section{Aim of Study \\ Objectives}

To compare the efficacy of Ondansetron, Metoclopramide and placebo in the prevention of post-operative nausea and vomiting in patients undergoing gynaecological laparoscopy.

\section{MATERIALS AND METHODS}

It is a clinical study of the comparison of efficacy of Ondansetron, Metoclopramide and placebo in the prevention of post-operative nausea and vomiting in 60 patients in the age group 20 - 39 years undergoing gynaecological laparoscopic surgeries. All of them belonged to ASA Grade I and II. The patients were informed about the nature of the study and written consent was obtained from them.

\section{Study Design}

Clinical study of the comparison of efficacy of Ondansetron, Metoclopramide and placebo in the prevention of postoperative nausea and vomiting in 60 patients in the age group 20 - 39 years undergoing gynaecological laparoscopic surgeries.

\section{Study Population}

60 patients were randomised to 3 groups of 20 each to receive either Inj. Ondansetron $4 \mathrm{mg}$ IV (Group I), Inj. Metoclopramide $10 \mathrm{mg}$ IV (Group II) and Inj. 0.9\% Normal saline as placebo (Group III) and those satisfying inclusion and exclusion criteria.

\section{Inclusion Criteria}

a. Female patients in the age group 20 - 39 years undergoing laparoscopic gynaecological surgeries.

b. ASA Grade 1 and 2.

c. Those patients with written consent.

\section{Exclusion Criteria}

a. Patients who had received any other anti-emetic or psychotropic medications within 24 hours before surgery.

b. Patients with history of motion sickness or parkinsonism.

c. Pregnant patients.

d. Morbidly obese patients.

e. Patients with hypersensitivity to studied drugs.

f. Patients who had vomiting or retching 24 hours prior to surgery.

\section{Methods}

After obtaining the approval from the Hospital Ethical Committee and the written informed consent from the patients, the patients were randomised to 3 groups of 20 each. Group I is those who received Inj. Ondansetron $4 \mathrm{mg}$ IV. Group II is those who received Inj. Metoclopramide $10 \mathrm{mg}$ IV. Group III is placebo (those who received Inj. 0.9\% normal saline).

A double-blind design was used and the drugs were administered 5 minutes before induction of anaesthesia. All patients were assessed for fitness of anaesthesia preoperatively and were given nil per oral 6 hours prior to surgery. The age and weight of the patients were noted. The basal heart rate, blood pressure and respiratory rate were noted for the comparison with the intra-operative and postoperative values. The anaesthesia machine was checked and all the equipment necessary for conducting general anaesthesia were kept ready. An 18-Gauge IV cannula was introduced to one of the forearms and a ringer lactate infusion was started. Inj. Pethidine $25 \mathrm{mg}$ IV was given 10 minutes before induction of anaesthesia.

A double-blind design was used and the drugs were labelled as DRUG O, DRUG P and DRUG M. These drugs were administered 5 minutes before the induction of anaesthesia. Anaesthesia was induced with Inj. Thiopentone sodium 3 - 5 $\mathrm{mg} / \mathrm{kg}$ IV and Inj. Succinylcholine $1-2 \mathrm{mg} / \mathrm{kg}$ IV. The time of induction was noted. Anaesthesia was maintained with $60 \%$ nitrous oxide in $\mathrm{O}_{2}$ and Inj. Vecuronium $0.08-0.1 \mathrm{mg} / \mathrm{kg}$ IV. The time of surgical incision was noted and all the patients received $500 \mathrm{~mL}$ ringer lactate during surgery and the immediate post-operative period. Standard monitoring in all cases included Pulse rate, BP, ECG and $\mathrm{SPO}_{2}$ and readings were charted. The time of removal of laparoscope was noted. At the end of surgery, residual neuromuscular blockade was reversed with Inj. Neostigmine $0.05 \mathrm{mg} / \mathrm{kg}$ and Inj. Atropine $0.02 \mathrm{mg} / \mathrm{kg}$. Following extubation, patients were maintained on supplemental $\mathrm{O}_{2}$ until awake. The time of recovery was noted. The duration of surgery and duration of anaesthesia were calculated and recorded. Early post-operative analgesia if required was given with Inj. Diclofenac $75 \mathrm{mg}$ IM and IV fluids continued over the first post-operative hour. The patients were assessed for a period of 24 hours after recovery for - 1) Nausea, vomiting. Nausea scoring was made as follows -

Grade 0 - No nausea.

Grade 1 - Mild nausea.

Grade 2 - Moderate nausea.

Grade 3 - Severe nausea.

1. When the patients complained of nausea or vomiting, Inj. Promethazine $25 \mathrm{mg}$ IM was given and time of injection was noted.

2. For vitals - pulse rate, BP and respiration at $1,2,4,6,12$ and 24 hours after surgery.

3. Time to first oral fluids (Oral fluids were offered at 2 hours after the procedure or before if requested and the time to first oral fluid is noted.

4. Time of ambulation.

5. Side effects like headache, sedation, dizziness and extrapyramidal symptoms. 


\section{Sample Size}

60 female patients in the age group 20 - 39 years undergoing laparoscopic gynaecological surgeries were studied in 3 groups of 20 each and the patients who were admitted for diagnostic laparoscopy in at SAT Hospital, Government Medical College, Trivandrum.

\section{Statistical Analysis}

Data were analysed statistically by considering the variables such as age, weight, BP, heart rate, respiratory rate, frequency of nausea and vomiting and other outcome measures and the effectiveness of two anti-emetic drugs were compared to the control group.

\section{RESULTS}

\begin{tabular}{|c|c|c|c|c|c|c|}
\hline Age in & \multicolumn{2}{|c|}{ Control } & \multicolumn{2}{c|}{ Ondansetron } & \multicolumn{2}{c|}{ Metoclopramide } \\
\cline { 2 - 7 } Years & & & & & & \\
\hline $20-29$ & 9 & 45 & 9 & 45 & 12 & 60 \\
\hline $30-39$ & 11 & 55 & 11 & 55 & 8 & 40 \\
\hline Total & $\mathbf{2 0}$ & $\mathbf{1 0 0}$ & $\mathbf{2 0}$ & $\mathbf{1 0 0}$ & $\mathbf{2 0}$ & $\mathbf{1 0 0}$ \\
\hline
\end{tabular}

Table 1. Distribution of Cases according to Age $\left(\mathrm{X}^{2}=1.1 ; \mathrm{d}-\mathrm{f}=1 ; \mathrm{p}>0.05\right)$

\begin{tabular}{|c|c|c|c|c|c|c|}
\hline Weight in Kg & \multicolumn{2}{|c|}{ Control } & \multicolumn{2}{c|}{ Ondansetron } & \multicolumn{2}{c|}{ Metoclopramide } \\
\hline $40-49$ & No & $\%$ & No & $\%$ & No & $\%$ \\
\hline $50+$ & 8 & 40 & 6 & 30 & 7 & 35 \\
\hline & 12 & 60 & 14 & 70 & 13 & 65 \\
\hline \multicolumn{7}{|c|}{ Table 2. Weight } \\
\hline
\end{tabular}

\begin{tabular}{|c|c|c|c|c|c|c|c|}
\hline \multirow{2}{*}{ Time of Assessment } & \multicolumn{2}{|c|}{ Control } & \multicolumn{2}{c|}{ Ondansetron } & \multicolumn{2}{c|}{ Metoclopramide } \\
\cline { 2 - 8 } & Normal & Mean & Range & Mean & Range & Mean & Range \\
\hline Pre-operative & $60-100$ & 83.9 & $76-100$ & 83.5 & $72-90$ & 84.2 & $74-100$ \\
\hline Intra-operative & $60-100$ & 83.55 & $76-90$ & 83.55 & $77-94$ & 83.25 & $77-90$ \\
\hline Post-operative & $60-100$ & 83.3 & $76-85$ & 84 & $80-90$ & 82.95 & $73-89$ \\
\hline \multicolumn{7}{|c|}{ Table 3. Table showing Mean, Range and Normal Heart Rate } \\
\hline
\end{tabular}

\begin{tabular}{|c|c|c|c|c|c|c|c|}
\hline \multirow{2}{*}{ Time of Assessment } & \multirow{2}{*}{ Normal } & \multicolumn{2}{|c|}{ Control } & \multicolumn{2}{c|}{ Ondansetron } & \multicolumn{2}{c|}{ Metoclopramide } \\
\cline { 3 - 8 } & & Mean & Range & Mean & Range & Mean & Range \\
\hline Pre-operative & $90-140$ & 122.7 & $110-150$ & 122.2 & $110-140$ & 123.7 & $110-150$ \\
\hline Intra-operative & $90-140$ & 121.25 & $110-140$ & 125.4 & $114-138$ & 124.4 & $112-140$ \\
\hline Post-operative & $90-140$ & 121.15 & $110-138$ & 122.3 & $110-138$ & 124.45 & $114-136$ \\
\hline \multicolumn{7}{|c|}{ Table 4. Systolic Blood Pressure } \\
\hline
\end{tabular}

\begin{tabular}{|c|c|c|c|c|c|c|c|}
\hline \multirow{2}{*}{ Time of Assessment } & \multirow{2}{*}{ Normal } & \multicolumn{2}{|c|}{ Control } & \multicolumn{2}{|c|}{ Ondansetron } & \multicolumn{2}{|c|}{ Metoclopramide } \\
\hline & & Mean & Range & Mean & Range & Mean & Range \\
\hline Pre-operative & $70-90$ & 82.4 & $70-94$ & 81.3 & $70-96$ & 82.3 & $70-90$ \\
\hline Intra-operative & $70-90$ & 81.35 & $70-90$ & 81.7 & $72-90$ & 82.35 & $72-96$ \\
\hline Post-operative & $70-90$ & 80.15 & $71-90$ & 81.7 & $70-90$ & 81.9 & $76-86$ \\
\hline
\end{tabular}

\begin{tabular}{|c|c|c|c|c|c|c|}
\hline Duration of Surgery & \multicolumn{3}{|c|}{ Control } & \multicolumn{2}{c|}{ Ondansetron } & \multicolumn{3}{c|}{ Metoclopramide } \\
\cline { 2 - 7 } in Minutes & No & $\%$ & No & $\%$ & No & $\%$ \\
\hline Below 30 Mins. & 14 & 70 & 16 & 80 & 14 & 70 \\
\hline Above 30 Mins. & 6 & 30 & 4 & 2 & 6 & 30 \\
\hline \multicolumn{3}{|c|}{ Table 6. Duration of Surgery } \\
\hline
\end{tabular}

$\left(X^{2}=0.63 ;\right.$ d.f $\left.=1 ; p>0.05\right)$

\begin{tabular}{|c|c|c|c|c|c|c|}
\hline $\begin{array}{c}\text { Duration of } \\
\text { Anaesthesia } \\
\text { in Minutes }\end{array}$ & \multicolumn{2}{|c|}{ Control } & \multicolumn{2}{c|}{ Ondansetron } & \multicolumn{2}{c|}{ Metoclopramide } \\
\cline { 2 - 7 } & $\%$ & No & $\%$ & No & $\%$ \\
\hline Upto 30 Mins. & 8 & 40 & 11 & 55 & 10 & 50 \\
\hline $\begin{array}{c}\text { More Than } \\
\text { 30 Mins. }\end{array}$ & 12 & 60 & 9 & 45 & 10 & 50 \\
\hline \multicolumn{3}{|c|}{ Table 7. Duration of Anaesthesia } \\
\hline
\end{tabular}

$\left(X^{2}=0.82 ;\right.$ d.f $\left.=2 ; p>0.05\right)$

\begin{tabular}{|c|c|c|c|c|}
\hline \multirow{2}{*}{ Duration } & \multicolumn{2}{|c|}{$\begin{array}{c}\text { Mean +/- SD Frequency } \\
\text { of Nausea or Vomiting }\end{array}$} & $\begin{array}{c}\text { t } \\
\text { Value }\end{array}$ & $\begin{array}{c}\text { p } \\
\text { Value }\end{array}$ \\
\cline { 2 - 3 } & $\begin{array}{c}\text { Control } \\
\text { Ondansetron }\end{array}$ & & \\
\hline $\begin{array}{c}\text { After } 1 \\
\text { Hour }\end{array}$ & $\begin{array}{c}0.8+/- \\
0.89\end{array}$ & $\begin{array}{c}0.1+/- \\
0.45\end{array}$ & 3.14 & $\mathrm{P}<0.01$ \\
\hline $\begin{array}{c}\text { After } 2 \\
\text { Hours }\end{array}$ & $\begin{array}{c}01.35+/- \\
1.04\end{array}$ & $\begin{array}{c}0.1+/- \\
0.05\end{array}$ & 4.94 & $\mathrm{P}<0.01$ \\
\hline After 4 & $\begin{array}{c}2.05+/- \\
\text { Hours }\end{array}$ & $\begin{array}{c}0.5+/- \\
1.39\end{array}$ & 3.9 & $\mathrm{P}<0.001$ \\
\hline
\end{tabular}

\begin{tabular}{|c|c|c|c|c|}
\hline $\begin{array}{c}\text { After } 6 \\
\text { Hours }\end{array}$ & $\begin{array}{c}1.65+/- \\
1.98\end{array}$ & $\begin{array}{c}0.4+/- \\
0.99\end{array}$ & 2.53 & $\mathrm{P}<0.05$ \\
\hline \multicolumn{3}{|c|}{ Table 8. Comparison of Frequency of Nausea and } \\
Vomiting between Control and Ondansetron \\
\hline
\end{tabular}

The reduction obtained in the frequency of nausea and vomiting in the ondansetron group was statistically significant. Hence, ondansetron definitely had anti-emetic effect at a higher level.

\begin{tabular}{|c|c|c|c|c|}
\hline \multirow[t]{2}{*}{ Duration } & \multicolumn{2}{|c|}{$\begin{array}{c}\text { Mean +/- SD of Frequency } \\
\text { of Nausea or Vomiting }\end{array}$} & \multirow{2}{*}{$\begin{array}{c}\mathrm{t} \\
\text { Value }\end{array}$} & \multirow{2}{*}{$\underset{\text { Value }}{\mathbf{p}}$} \\
\hline & Control & Metoclopramide & & \\
\hline $\begin{array}{l}\text { After } 1 \\
\text { Hours }\end{array}$ & $0.8+/-0.89$ & $0.5+/-0.94$ & 1.03 & $\mathrm{p}>0.05$ \\
\hline $\begin{array}{l}\text { After } 2 \\
\text { Hours }\end{array}$ & $1.35+/-1.04$ & $0.95+/-1.1$ & 1.18 & $p>0.05$ \\
\hline $\begin{array}{l}\text { After } 4 \\
\text { Hours } \\
\end{array}$ & $2.05+/-1.39$ & $1.55+/-1.7$ & 1.02 & $p>0.05$ \\
\hline $\begin{array}{l}\text { After } 6 \\
\text { Hours }\end{array}$ & $1.65+/-1.98$ & $1.35+/-1.755$ & 0.51 & $p>0.05$ \\
\hline
\end{tabular}

The statistical test for equality of means (' $\mathrm{t}$ ' test) revealed that all differences are not significant $(p>0.05)$. So it is 
evident that the mean frequency of nausea/vomiting in the Metoclopramide group was at par with the control group and hence no appreciable antiemetic effect is attributable to Metoclopramide compared to Ondansetron group.

\begin{tabular}{|c|c|c|c|c|}
\hline \multirow{2}{*}{ Group } & \multicolumn{2}{|c|}{$\begin{array}{c}\text { Time taken for } \\
\text { the 1st Episode } \\
\text { of Vomiting }\end{array}$} & \multirow{2}{*}{ S. D. } & \multirow{2}{*}{ P Value } \\
\cline { 2 - 5 } & No & $\begin{array}{c}\text { Mean } \\
\text { (Hours) }\end{array}$ & & \\
\hline Control & 11 & 5.27 & 1.009 & $\mathrm{p}>0.05$ \\
\hline Ondansetron & 2 & 5 & 1.41 & $\mathrm{p}>0.05$ \\
\hline Metoclopramide & 7 & 4.9 & 1.03 & $\mathrm{p}>0.05$ \\
\hline & \multicolumn{7}{|c|}{ Table 10. Comparison of the Mean Time } \\
Taken for the First Episode of Vomiting \\
\hline
\end{tabular}

\begin{tabular}{|c|c|c|c|c|}
\hline \multirow{2}{*}{ Group } & \multicolumn{2}{|c|}{$\begin{array}{c}\text { Time taken for } \\
\text { the 1st Episode } \\
\text { of Nausea }\end{array}$} & \multirow{2}{*}{ S. D. } & \multirow{2}{*}{ P Value } \\
\cline { 2 - 5 } & No & $\begin{array}{c}\text { Mean } \\
\text { (Hours) }\end{array}$ & & \\
\hline Control & 17 & 1.45 & 1 & \\
\hline Ondansetron & 5 & 3.8 & 1.8 & $\mathrm{p}<0.05$ \\
\hline Metoclopramide & 11 & 2.13 & 1.55 & $\mathrm{p}>0.05$ \\
\hline \multicolumn{2}{|c|}{$\begin{array}{r}\text { Table 11. Comparison of the Mean Time } \\
\text { Taken for the First Episode of Nausea }\end{array}$} \\
\hline
\end{tabular}

Here, a delayed effect of Ondansetron was seen for reporting the first episode of nausea.

\begin{tabular}{|c|c|c|c|c|}
\hline Type of & \multicolumn{2}{|c|}{ Nausea Present } & \multicolumn{2}{c|}{ Nausea Absent } \\
\cline { 2 - 5 } Antiemetic Drug & No & $\%$ & No & \% \\
\hline Placebo (Control) & 17 & 85 & 3 & 15 \\
\hline Ondansetron & 5 & 25 & 15 & 75 \\
\hline Metoclopramide & 11 & 55 & 9 & 45 \\
\hline Table 12. Association between Incidence \\
of Nausea and Type of Drug \\
\hline
\end{tabular}

Here, a remarkable reduction was obtained with Ondansetron. The statistical test for association (Chi square test) showed a strong association between the type of antiemetic drug and the incidence of nausea. $\left(X^{2}=10.22 ; d-f=2 ; p<0.01\right)$

\begin{tabular}{|c|c|c|c|c|}
\hline \multirow{2}{*}{$\begin{array}{c}\text { Type of } \\
\text { Antiemetic Drug }\end{array}$} & \multicolumn{2}{|c|}{ Vomiting Present } & \multicolumn{2}{|c|}{ Vomiting Absent } \\
\hline & No & $\%$ & No & $\%$ \\
\hline Placebo (Control) & 11 & 55 & 9 & 45 \\
\hline Ondansetron & 2 & 10 & 18 & 90 \\
\hline Metoclopramide & 7 & 35 & 13 & 65 \\
\hline $\begin{array}{r}\text { Table } 13 . \\
\text { of } \mathrm{V}\end{array}$ & $\begin{array}{l}\text { SSOci } \\
\text { nitin }\end{array}$ & Type & $\begin{array}{l}\text { Incide } \\
\text { rug }\end{array}$ & \\
\hline
\end{tabular}

In this case also, the association between antiemetic drug and incidence of vomiting was found to be statistically significant.

\begin{tabular}{|c|c|c|c|c|}
\hline \multirow{2}{*}{ Group } & \multicolumn{3}{|c|}{ Initiation of Inj. Promethazine } \\
\cline { 2 - 5 } & \multicolumn{2}{|c|}{ Necessitated } & \multicolumn{2}{c|}{ Not Necessitated } \\
\hline No & $\%$ & No & $\%$ \\
\hline $\begin{array}{c}\text { Placebo } \\
\text { (Control) }\end{array}$ & 10 & 50 & 10 & 50 \\
\hline Ondansetron & 2 & 10 & 18 & 90 \\
\hline Table 14. Association between Initiation of Inj. \\
Promethazine and Type of Drug \\
\hline
\end{tabular}

\begin{tabular}{|c|c|c|c|c|c|c|}
\hline Side Effects & \multicolumn{2}{|c|}{ Ondansetron } & \multicolumn{2}{l|}{ Metoclopramide } & \multicolumn{2}{l|}{$\begin{array}{c}\text { Placebo } \\
\text { (Control) }\end{array}$} \\
\hline & No & \% & No & \% & No & $\%$ \\
\hline Sedation & Nil & 0 & 3 & 15 & Nil & 0 \\
\hline Dizziness & Nil & 0 & 2 & 10 & Nil & 0 \\
\hline Headache & Nil & 0 & Nil & 0 & Nil & 0 \\
\hline $\begin{array}{c}\text { Extra } \\
\text { pyramidal } \\
\text { Symptoms }\end{array}$ & Nil & 0 & Nil & 0 & Nil & 0 \\
\hline \multicolumn{7}{|c|}{ Table 15. Side Effects } \\
\hline
\end{tabular}

\section{DISCUSSION}

Post-operative nausea and vomiting remains a common problem after general anaesthesia and contribute to patient's dissatisfaction. Emetic symptoms can delay the discharge and result in unplanned hospital stay. ${ }^{(6)}$

A variety of risk scoring system has been introduced in an attempt to improve the use of antiemetic agents. The use of propofol in a non-sedative doses reduces the incidence of post-operative nausea and vomiting in $50 \%$ of patients. (7)

The most commonly used antiemetic medications are anti-histamines, anti-cholinergic, promethazine, phenothiazine group of drugs and dopamine receptor antagonists.(8) But these drugs have side effects like hypotension, sedation, restlessness, dysphoria and extrapyramidal symptoms, usually more common in patients on phenothiazine ${ }^{(9)}$ and can be managed with antihistamines and benzodiazepines.

Antihistamines like dimenhydrinate, hydroxyzine are antihistaminic compounds that acts on central vomiting centre and vestibular pathways to prevent PONV, useful in motion-induced vomiting and patients for middle ear and strabismus surgeries.(10)

Ondansetron is a selective antagonist of 5HT3 receptors. The 5HT receptors appears to mediate physiologic responses, both in the peripheral nervous system and in the vomiting centre of central nervous system.(11) Clinical studies have demonstrated that 5HT3 receptor antagonists decrease retching and vomiting in response to cytotoxic drugs.

Ondansetron was the first serotonin antagonist and its introduction was a milestone in prevention of early chemotherapy-induced vomiting. Ondansetron and its congeners like granisetron, dolasetron, palonosetron are highly selective 5HT3 receptor antagonists; are consistently more effective with less side effects.(12,13)

Metoclopramide has been used for decades to prevent post-operative nausea and vomiting. It has got antidopaminergic, anti-serotonin effect and gastric prokinetic effect.(14)

Raphel JH and Nortun AC in a double-blind study compared the prophylactic effect of Ondansetron with that of Metoclopramide in 123 patients undergoing general anaesthesia for day-case gynaecological laparoscopic surgeries. ${ }^{15,16)}$ The number of patients with nausea and vomiting in the Ondansetron group was $28 \%$ compared to $53 \%$ in the Metoclopramide group.

Malins AF et al in 1994 compared the incidence of PONV after day-case gynaecological laparoscopy after oral premedication with Ondansetron, Metoclopramide and placebo and found that $26 \%$ patients in the Ondansetron group, $42 \%$ 
in the Metoclopramide group and $50 \%$ in the placebo group had emesis.(17)

Philip S et al in 1993 studied the effect of Ondansetron in different doses and found that Ondansetron in doses less than $8 \mathrm{mg}$ is a safe and effective antiemetic for treatment of postoperative nausea and vomiting.(18)

Recent studies suggest that traditional techniques like TENS, Acupressure may be useful additives to the conventional antiemetic drug therapy.(19)

In the present study, the incidence of nausea was significantly lower in the Ondansetron group (25\%) compared to other groups (Metoclopramide group 55\% and Control group 85\%). Also more than one-fourth reduction was seen with Ondansetron group compared to other groups. These findings were in quite agreement with earlier studies on Ondansetron by Raphel JH and Nortun AC. The vital signs namely pulse rate, BP and respiration were within normal limits, since no studied drug had any significant effects on the vital signs of the patient. This finding was similar to the studies by Philip S et al and Ray M et al.

In this study, the mean frequency of nausea and vomiting was lesser in Ondansetron group. This conclude that Ondansetron definitely has good antiemetic effect. This study shows that no appreciable antiemetic effect was attributable to Metoclopramide group. Direct comparison of Ondansetron $4 \mathrm{mg}$ with Metoclopramide $10 \mathrm{mg}$ and placebo showed that Ondansetron was superior for prophylaxis against PONV.

\section{CONCLUSION}

In conclusion, the study proved that Ondansetron was superior to Metoclopramide for prophylaxis against PONV after gynaecological laparoscopic surgeries. In this study, the incidence of nausea was significantly lower in the Ondansetron group (25\%) compared to other groups.

\section{REFERENCES}

[1] White PF. Text book of ambulatory anesthesia and surgery. London: WB Saunders 1997.

[2] Eberhart LH, Morin AM, Wulf $\mathrm{H}$, et al. Patient preferences for immediate postoperative recovery. $\mathrm{Br}$ J Anesthesia 2002;89(5):760-1.

[3] Beattie W, Lindbald T, Buckley DN, et al. Menstruation increases the risk of nausea and vomiting after laparoscopy. A prospective randomized study. Anaesthesiology 1993;78(2):272-6.

[4] Bodner M, White PF. Antiemetic efficiency of ondansetron after outpatient laparoscopy. Anesth Analg 1991;73(3):250-4.

[5] Apfel CC, Laara E, Koivuranta M, et al. A simplified risk score for predicting postoperative nausa and vomiting: conclusions from cross-validations between two centers. Anesthesiology 1999;91(3):693-700.
[6] Gold BS, Kitz DS, Lecky JH, et al. Unanticipated admission to hospital following ambulatory surgery. JAMA 1989;262(21):3008-10.

[7] Gan TJ, Glass PSA, Howel ST, et al. Determination of plasma concentrations of propofol associated with $50 \%$ reduction in postoperative nausea. Anesthesiology 1997;87:779-84.

[8] Watcha ME, White PF. New antiemetic drugs. Int Anesthesiol Clin 1995;33(1):1-20.

[9] Parlac I, Erdur B. Midazolam versus diphenylhy draminefor the treatment of metoclopramide induced akarthisia, a randomized control study. ACAD Emerg Med 2007;14:715-21.

[10] Vener DF, Carr AS, Sikich N, et al. Dimenhydrinate decreases vomiting after strabismus surgery in children. Anesth Analg 1996;82(4):728-31.

[11] Andrews PL. Physiology of nausea and vomiting. Br J Anaesth 1992;69(7 Suppl 1):2S-19S.

[12] Khalil SN, Kataria B, Pearson K, et al. Ondansetron prevents post op nausea and vomiting in women out patients. Anesth Analgesia 2004;98:1666-9.

[13] Bodner M, White PF. Antiemetic effect of ondansetron after outpatient laparoscopy. Anesth Analg 1991;73(3):250-4.

[14] Freidenberg FK, Parkman HP. Advances in the management of gastroparesis. Cur Treat Options Gastorenterol 2007;10(4):283-93.

[15] Raphael JH, Norton AC. Antiemetic efficacy of prophylactic Ondansetron in laparoscopic surgery. Randomized, double blind comparison with metoclopramide. British Journal of Anaesthesia 1993;71(6):845-8.

[16] McKenzie R, Kovac A, O'Connor T, et al. Comparison of ondansetron versus placebo to prevent post-operative nausea and vomiting in women undergoing ambulatory gynecologic surgery. Anaesthesiology 1993;78(1):21-8.

[17] Malins Af, Field JM, Nesling PM, et al. Nausea and vomiting after gynaecological laparoscopy: comparison of premedication with oral ondansetron, metoclopramide and placebo. British Journal of Anaesthesia 1994;72:231-3.

[18] Matson A, Palazzo M. Post-operative nausea and vomiting. In: Adams AP, Cashman JN. eds. Recent advances in anaesthesia and analgesia. No 19. London: Churchill Livingstone 1995;19:107-126.

[19] White PF. Use of alternative medical therapies in the perioperative period: is it time to get on board? Anesth Analg 2007;104(2):251-7. 